\title{
TINGKAT KEPUASAN PESERTA WORKSHOP MEDIA PEMBELAJARAN BERBASIS ANDROID
}

\author{
Monica Fransisca1), Yuliawati Yunus ${ }^{1)}$, Renny Permata Saputri'1) \\ 1)Pendidikan Teknik Informatika, Fakultas Keguruan dan IImu Pendidikan, Universitas Putra Indonesia YPTK Padang, \\ Padang, Sumatera Barat, Indonesia \\ Corresponding author : Monica Fransisca \\ E-mail : monicafransisca@upiyptk.ac.id
}

Diterima 03 Oktober 2021, Direvisi 19 Oktober 2021, Disetujui 19 Oktober 2021

\begin{abstract}
ABSTRAK
Kegiatan pengabdian kepada masyarakat berlandaskan pada dua masalah yaitu kondisi pandemi yang mengubah proses pembelajaran dan perkembangan teknologi pada media pembelajaran, berdasarkan pada masalah tersebut maka perlu dilaksanakan pelatihan perancangan media ajar android bagi mahasiswa Praktek Lapangan Kependidikan (PLK) di Fakultas Keguruan dan IImu Pendidikan, Universitas Putra Indonesia YPTK Padang. Tujuan pelatihan adalah untuk membantu mahasiswa PLK dalam mengembangkan media pembelajaran yang dapat dimanfaatkan secara jarak jauh. Pelatihan dilaksanakan secara daring karena keterbatasan tempat dan keadaan yang tidak memungkinkan untuk pelatihan secara tatap muka. Metode pengabdian adalah berupa workshop atau pelatihan dengan rincian tahapan persiapan, screening, implementasi, evaluasi, dan laporan. Kegiatan pengabdian dilakukan secara bertahap mulai dari pengenalan media, teori media, dan simulasi pembuatan media berbasis android. Peserta dari kegiatan pengabdian berjumlah sebanyak 36 orang yang terdiri dari mahasiswa program studi pendidikan teknik informatika. Setelah kegiatan pelatihan selesai dilaksanakan, semua peserta diminta untuk mengisi kuesioner penilaian pelatihan. Kuesioner ini bertujuan untuk melihat tingkat kepuasan peserta terhadap pelatihan pembuatan media pembelajaran berbasis android. Indikator penilaian kuesioner terdiri atas empat aspek yang mencakup 18 pernyataan. Hasil pengisian kuesioner dari peserta menunjukkan tingkat kepuasaan berada pada rata-rata persentase $90 \%$. Maka dapat disimpulkan bahwa peserta merasa sangat puas dengan kegiatan pelatihan pembuatan media pembelajaran berbasis android.
\end{abstract}

Kata kunci: android; media pembelajaran; workshop

\begin{abstract}
This community service activity was based on two problem such as pandemic situation changed the learning process and technological developments in learning media, based on those problem it's important to conducting a workshop on creating android-based learning media which aimed for teacher students at Faculty of Teacher Training and Education, Universitas Putra Indonesia YPTK Padang. The training purpose was to assisted teacher students in developing learning media that can be used remotely. Training was carried out online due to limited space and circumstances. This activity used a workshop method which contains with steps of preparations, screening, implementation, evaluation and reports. Training activity was consists of a few stages such as media introduction, media theory, and simulations. The participant's amounts were 36 students of informatics engineering education program. After the training activities were completed, all participants asked to fill out an assessment questionnaires. The questionnaires were aims to see the level of participant's satisfaction in the training. The questionnaires contain with 18 statements as an indicator, and consist of four main aspects. The questionnaires results from participants showed that the level of satisfaction is $90 \%$ in average. So it can be concluded that the participants were very satisfied with training activities.
\end{abstract}

Keywords: android; learning media; workshop.

\section{PENDAHULUAN}

Media pembelajaran mempunyai peran yang sangat penting di dalam kegiatan pembelajaran, media yang baik dapat membantu kegiatan pembelajaran menjadi lebih baik dan efektif. (Makaborang et al., 2021) dalam salah satu artikelnya membahas mengenai kegiatan pengabdian masyarakat yang bertemakan pembuatan serta penggunaan media pembelajaran. Berdasarkan pada artikel tersebut dapat disimpulkan bahwa dengan adanya media 
pembelajaran yang baik dan menarik dapat meningkatkan antusias siswa dalam kegiatan pembelajaran. Maka dari itu para pendidik dituntut untuk mampu merancang media pembelajaran yang baik sesuai dengan kebutuhan peserta didik.

Pernyataan tersebut sesuai dengan tulisan pada buku (Purba et al., 2020), yang membahas mengenai pentingnya media pembelajaran. Perkembangan dari media pembelajaran tidak terlepas dari perkembangan atau peningkatan akan kebutuhan media pembelajaran itu sendiri. Untuk merancang media pembelajaran yang baik harus disesuaikan dengan perkembangan media pembelajaran, serta perkembangan dari kebutuhan peserta didik, sesuai dengan pernyataan oleh (Pakpahan et al., 2020). (Pangga et al., 2021) mengemukakan bahwa media pembelajaran dapat berupa video yang dapat membantu dalam proses belajar. Pada artikelnya (Pangga et al., 2021) menyatakan bahwa pelatihan perancangan video pembelajaran bagi guru terbukti dapat menambah opsi pada media pembelajaran yang digunakan. Berikutnya pada artikel yang ditulis oleh (Fransisca et al., 2019) dinyatakan bahwa perkembangan media pembelajaran saat ini juga sangat besar dipengaruhi oleh perkembangan teknologi. Saat ini media pembelajaran tidak lagi terbatas berupa media offlline, akan tetapi sudah berkembang ke dalam bentuk media online.

Pemanfaatan media online ini terbukti mampu meningkatkan ketertarikan siswa dalam pembelajaran serta dapat meningkatkan hasil belajar secara efektif. Berdasarkan pada hasil penelitian oleh Saputri \& Fransisca (2020b) dan Yunus \& Fransisca (2020) juga diketahui bahwa kebutuhan siswa terhadap media pembelajaran online cukup tinggi, terutama dalam kondisi pandemi saat ini dimana pembelajaran tatap muka sangat dibatasi. Tingginya tingkat kebutuhan siswa terhadap media pembelajaran online ini juga terlihat pada tingginya kemampuan siswa dalam penggunaan media online, pernyataan tersebut juga dikutip dari artikel (Yunus \& Fransisca, 2020).

Media pembelajaran online dapat berupa media yang berbasiskan web, ataupun berbasiskan platform android. Penggunaan android adalah salah satu media pendukung pembelajaran. Saputri \& Fransisca (2020a) menyatakan pada salah satu artikelnya bahwa media pembelajaran yang berbasiskan platform android dapat mempermudah proses pembelajaran terutama untuk pembelajaran daring atau dalam jaringan. Terutama dalam kondisi pandemi covid-19 yang menyebabkan kondisi pembelajaran mengalami perubahan, dari pembelajaran tatap muka menjadi pembelajaran daring. Dalam kondisi pembelajaran daring tersebut sangat dibutuhkan media yang mampu mendukung semua kebutuhan pendidik dan siswa agar pembelajaran tetap dapat berjalan dengan semestinya, dikutip dari tulisan (Atsani, 2020).

Kegiatan belajar yang berlangsung saat ini setelah pandemi yang melanda pada awal tahun 2020, mengalami perubahan yang sangat besar. Sebagian besar pembelajaran berubah ke dalam bentuk daring atau dalam jaringan, dari yang sebelumnya pembelajaran bersifat tatap muka atau offline. Perubahan kondisi ini memberikan pengaruh yang sangat besar baik bagi guru ataupun siswa. Setiap guru dituntut untuk mampu menyampaikan pembelajaran walaupun dengan segala keterbatasan yang ada. Hal ini tentu juga berpengaruh terhadap calon guru atau mahasiswa Praktek Lapangan Kependidikan (PLK) yang masih minim pengetahuan lapangan.

Observasi awal pada program studi Pendidikan Teknik Informatika di Fakultas Keguruan dan IImu Pendidikan, Universitas Putra Indonesia YPTK Padang menunjukkan bahwa mayoritas mahasiswa menguasai media pembelajaran offline, dan sebagian sudah mengetahui mengenai media pembelajaran online. Untuk itu dirasa perlu diadakan sebuah workshop atau pelatihan media pembelajaran khususnya pada media pembelajaran yang berbasiskan pada teknologi terutama online.

Berdasarkan pada beberapa referensi tersebut dan hasil observasi awal pada lokasi tujuan kegiatan pengabdian masyarakat maka dapat disimpulkan bahwa media pembelajaran yang memanfaatkan teknologi sangat dibutuhkan oleh pendidik. Terutama bagi para calon pendidik, dalam hal ini adalah mahasiswa Praktek Lapangan Kependidikan (PLK) khususnya pada Fakultas Keguruan dan IImu Pendidikan di Universitas Putra Indonesia YPTK Padang. Dari hasil observasi awal ditemukan bahwa calon mahasiswa PLK tersebut belum memahami cara pembuatan ataupun perancangan media pembelajaran online, khususnya pada platform android. Maka dari itu diperlukan adanya workshop atau pelatihan perancangan pembuatan media pembelajaran android. Jumlah peserta dari workshop ini adalah sebanyak 36 orang mahasiswa dari Program Studi Pendidikan Teknik Informatika, Fakultas Keguruan dan IImu Pendidikan, Universitas Putra Indonesia YPTK Padang.

\section{METODE}

Kegiatan pengabdian kepada masyarakat yang dilaksanakan menggunakan 
metode pelatihan perancangan media pembelajaran berbasis android dan ditujukan kepada mahasiswa PLK Fakultas Keguruan dan IImu Pendidikan di Universitas Putra Indonesia YPTK Padang. Tahapan dari kegiatan pelatihan diuraikan dalam diagram berikut:

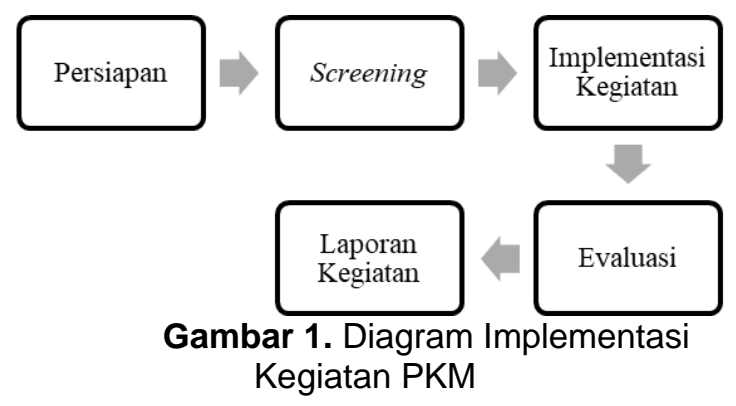

Pada diagram di atas dapat dilihat beberapa tahapan yang dilakukan yaitu mulai dari tahap persiapan, tahap screening, tahap implementasi kegiatan, tahap evaluasi, dan tahap laporan kegiatan. Setiap tahapan ini memiliki rincian proses masing-masingnya, dan harus dilaksanakan sesuai dengan urutan yang ada pada diagram implementasi tersebut.

Adapun pada tahap pertama yaitu persiapan, dilakukan beberapa kegiatan seperti survei peserta dan lokasi, pengurusan surat izin untuk pelaksanaan PKM, dilanjutkan dengan persiapan materi PKM. Tahap kedua yaitu screening, pada tahap ini kegiatan yang dilaksanakan adalah mempersiapkan pemateri serta panitia PKM, memastikan ketersediaan sarana PKM, serta memastikan kebutuhan kegiatan PKM seperti spanduk, dan platform online kegiatan PKM. Berikutnya tahap ketiga adalah implementasi kegiatan yaitu berupa pembukaan kegiatan PKM, penyampaian materi singkat mengenai tema PKM, pemaparan media android sebagai media pembelajaran, perancangan media pembelajaran berbasis android, pelaksanaan pelatihan perancangan media pembelajaran berbasis android. Kemudian pada tahap keempat dilakukan evaluasi dengan cara menggunakan kuesioner yang diberikan kepada peserta mengenai tingkat kepuasan peserta terhadap kegiatan pelatihan. Pada kuesioner di tahap evaluasi digunakan empat indikator utama sebagai penilaian kepuasan peserta yaitu aspek materi, aspek panitia, aspek suasana, dan aspek penggunaan media. Kegiatan pelatihan dinyatakan berhasil jika persentase kepuasan peserta berada di atas $81,26 \%$ sesuai pernyataan (Fuada et al., 2020). Berikut persentase tingkat kepuasan peserta workshop dirujuk dari (Fuada et al., 2020).
Tabel 1. Tingkat Kepuasan Peserta Workshop

\begin{tabular}{lcl}
\hline No & Persentase & \multicolumn{1}{c}{ Keterangan } \\
\hline 1. & $81,26 \%-100,00 \%$ & Sangat Puas \\
\hline 2. & $62,51 \%-81,25 \%$ & Puas \\
\hline 3. & $43,76 \%-62,50 \%$ & Tidak Puas \\
\hline 4. & $25,00 \%-43,75 \%$ & Sangat Tidak Puas \\
\hline & Tahap terakhir & adalah tahap kelima
\end{tabular}
yaitu berupa pembuatan laporan kegiatan PKM yang berisikan cakupan semua kegiatan mulai dari persiapan hingga evaluasi kegiatan.

\section{HASIL DAN PEMBAHASAN}

Kegiatan pengabdian kepada masyarakat ini ditujukan kepada mahasiswa PLK pada program studi Pendidikan Teknik Informatika, Fakultas Keguruan dan IImu Pendidikan, Universitas Putra Indonesia YPTK Padang. Adapun jumlah peserta adalah sebanyak 36 orang mahasiswa PLK yang akan melaksanakan PLK pada periode JuliDesember 2021. Pelatihan ini dilangsungkan tepatnya pada tanggal 18 Agustus 2021 dan dilaksanakan secara daring karena keterbatasan yang ada disebabkan oleh pandemi. Rincian kegiatan pelatihan adalah berupa pembinaan, edukasi, tutor, dan pelatihan yang disesuaikan dengan tujuan serta kebutuhan para peserta PKM. Pada akhir kegiatan PKM setiap peserta diminta untuk memberikan penilaian terhadap kegiatan PKM melalui kuesioner yang dibagikan melalui google form.

Hasil akhir dari kegiatan pelatihan ini menghasilkan sebuah media pembelajaran berbasis android yang dapat diakses oleh guru dan siswa melalui perangkat masing-masing. Media ini dapat diakses melalui perangkat yang berbasiskan android seperti smartphone. Pada media tersebut disediakan materi, soal latihan, serta video yang dapat membantu proses pembelajaran. Berikut beberapa gambaran dari hasil perancangan media pembelajaran berbasis android.

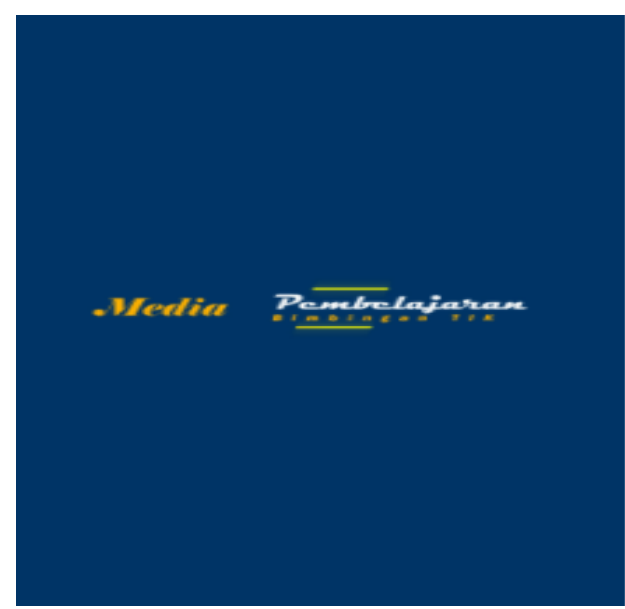

Gambar 2. Halaman Awal Media 
Gambar di atas merupakan tampilan awal media pembelajaran berbasis android. Tampilan ini akan muncul setelah mengklik ikon aplikasi android yang ada pada perangkat masing-masing. Setelah tampilan awal ini baru kemudian dapat dilihat halaman beranda, seperti dapat dilihat pada gambar berikut ini.

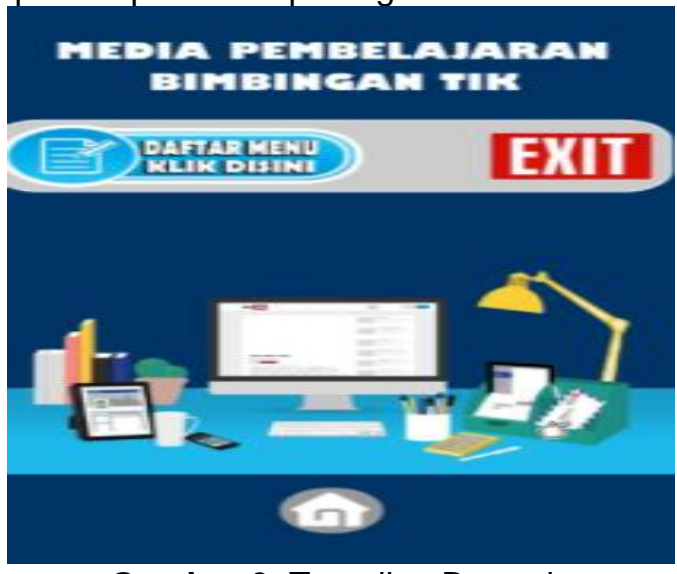

Gambar 3. Tampilan Beranda

Setelah tampilan halaman beranda selanjutnya dapat halaman menu yang dapat diakses oleh para guru dan siswa sesuai kebutuhan pembelajaran pada setiap pertemuannya.

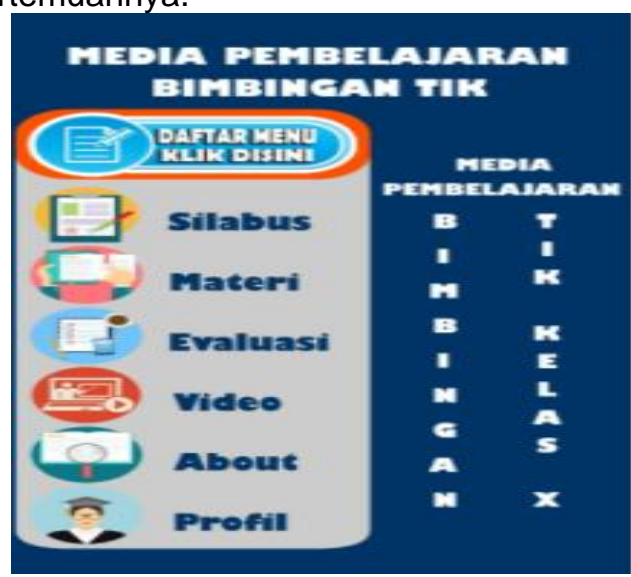

Gambar 4. Tampilan Menu

Pelatihan perancangan media pembelajaran berbasis android dapat diterima dengan baik oleh para peserta, dilihat dari antusiasme peserta mengikuti pelatihan tersebut. Hal ini dibuktikan dengan kehadiran peserta meskipun hanya melalui platform Google Meet yang dilaksanakan secara online. Jumlah kehadiran peserta tersebut mencapai persentase sebanyak 95\% dari seluruh mahasiswa PLK yang diundang.

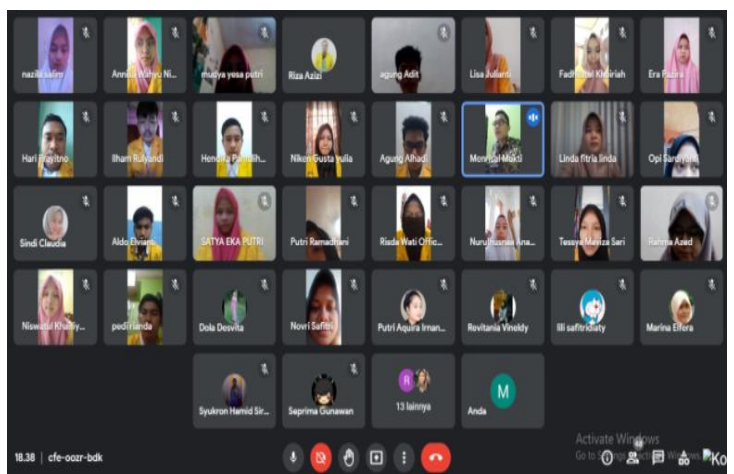

Gambar 5. Pelaksanaan PKM (1)

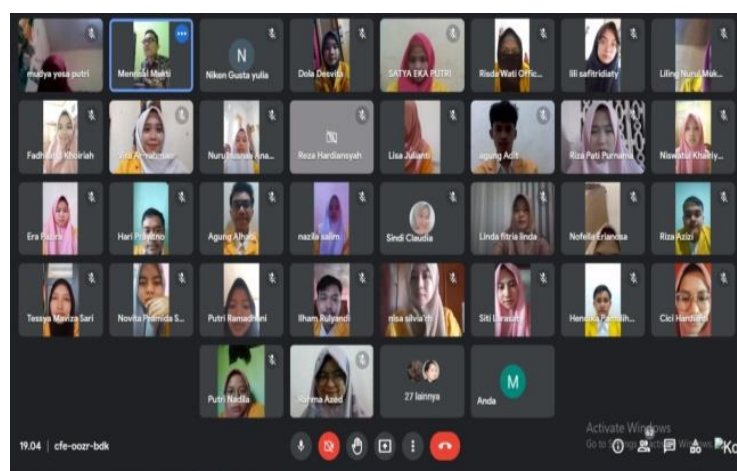

Gambar 6. Pelaksanaan PKM (2)

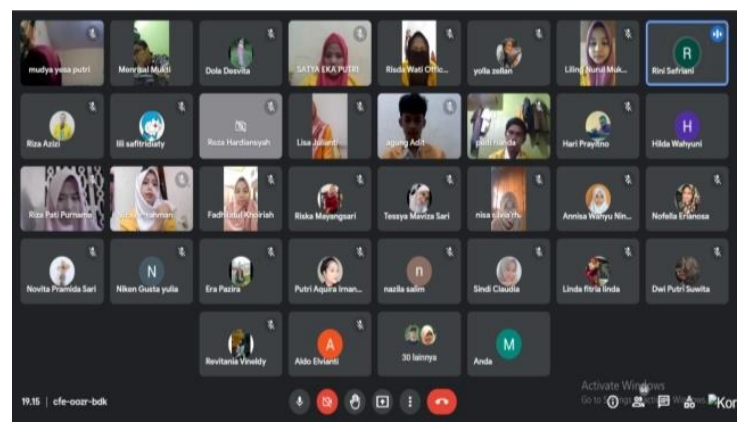

Gambar 7. Pelaksanaan PKM (3)

Hasil akhir dari kegiatan PKM ini adalah berupa keberhasilan mahasiswa PLK dalam merancang media pembelajaran berbasis android, dan tingkat keberhasilan ini berada pada persentase $50 \%$ dari jumlah peserta. Setelah pelatihan selesai dilaksanakan, setiap peserta diberikan kuesioner yang berisikan pernyataan tentang kepuasan peserta terhadap pelatihan tersebut. Kuesioner terbagi atas empat aspek yaitu aspek materi, aspek panitia, aspek suasana, dan aspek penggunaan media dengan jumlah pernyataan dari keempat aspek tersebut adalah sebanyak 18 pernyataan. Indikator tingkat kepuasan dinyatakan dengan penilaian berskala seperti berikut:

$$
\begin{aligned}
& 1=\text { Sangat Tidak Setuju (STS) } \\
& 2=\text { Tidak Setuju (TS) } \\
& 3=\text { Kurang Setuju (KS) } \\
& 4=\text { Setuju (S) } \\
& 5=\text { Sangat Setuju (SS) }
\end{aligned}
$$


Berikut dirincikan dalam tabel pernyataan yang disajikan dalam kuesioner beserta dengan penilaian yang disediakan.

Tabel 2. Pernyataan yang akan ditampilkan pada kuesioner

\begin{tabular}{llc}
\hline $\begin{array}{l}\text { A. Materi Workshop Media } \\
\text { Pembelajaran berbasis Android }\end{array}$ & Skor \\
\hline & $\begin{array}{l}\text { Materi workshop yang diberikan } \\
\text { sangat bermanfaat bagi kegiatan } \\
\text { pembelajaran }\end{array}$ & $1-5$ \\
\hline 2 & $\begin{array}{l}\text { Materi workshop yang diberikan } \\
\text { mudah dipahami dan dimengerti }\end{array}$ & $1-5$ \\
\hline 3 & $\begin{array}{l}\text { Cakupan materi workshop yang } \\
\text { diberikan lengkap sesuai dengan } \\
\text { kebutuhan }\end{array}$ & $1-5$ \\
\hline & $\begin{array}{l}\text { Materi workshop yang diberikan } \\
\text { sesuai dengan harapan dan } \\
\text { kebutuhan saya dalam kegiatan } \\
\text { pembelajaran }\end{array}$ & $1-5$ \\
\hline 5 & $\begin{array}{l}\text { Materi workshop yang diberikan dapat } \\
\text { saya pahami dan terima dengan baik }\end{array}$ & $1-5$ \\
\hline
\end{tabular}

\begin{tabular}{llc}
\hline $\begin{array}{l}\text { B. Panitia Workshop Media } \\
\text { Pembelajaran berbasis Android }\end{array}$ & Skor \\
\hline 1 & $\begin{array}{l}\text { Penjelasan materi workshop } \\
\text { disampaikan secara sistematis }\end{array}$ & $1-5$ \\
\hline 2 & $\begin{array}{l}\text { Panitia kegiatan workshop sangat } \\
\text { komunikatif }\end{array}$ & $1-5$ \\
\hline 3 & $\begin{array}{l}\text { Panitia kegiatan workshop menguasai } \\
\text { materi workshop dengan sangat baik }\end{array}$ & $1-5$ \\
\hline 4 & $\begin{array}{l}\text { Panitia workshop melaksanakan } \\
\text { kegiatan sesuai dengan jadwal yang } \\
\text { sudah ditetapkan }\end{array}$ & $1-5$ \\
\hline 5 & $\begin{array}{l}\text { Panitia workshop menyediakan waktu } \\
\text { untuk kegiatan diskusi selama dan } \\
\text { setelah kegiatan berlangsung }\end{array}$ & $1-5$ \\
\hline
\end{tabular}

\begin{tabular}{clc}
\hline $\begin{array}{l}\text { C. Suasana Kegiatan Workshop Media } \\
\text { Pembelajaran berbasis Android }\end{array}$ & Skor \\
\hline 1 & $\begin{array}{l}\text { Kegiatan workshop yang berlangsung } \\
\text { terasa membosankan }\end{array}$ & $1-5$ \\
\hline $\begin{array}{l}\text { Panitia kegiatan workshop mampu } \\
\text { menciptakan suasana workshop yang } \\
\text { menarik }\end{array}$ & $1-5$ \\
\hline 3 & $\begin{array}{l}\text { Kegiatan workshop memberikan } \\
\text { contoh pelatihan yang cukup baik }\end{array}$ & $1-5$ \\
\hline 4 & $\begin{array}{l}\text { Suasana kegiatan workshop yang } \\
\text { berlangsung tidak interaktif }\end{array}$ & $1-5$ \\
\hline 5 & $\begin{array}{l}\text { Panitia lainnya sangat membantu } \\
\text { selama kegiatan berlangsung }\end{array}$ & $1-5$ \\
\hline
\end{tabular}

\begin{tabular}{ll}
\hline $\begin{array}{l}\text { D. Penggunaan Media Workshop Media } \\
\text { Pembelajaran berbasis Android }\end{array}$ & Skor \\
\hline $1 \quad \begin{array}{l}\text { Modul yang diberikan tidak lengkap } \\
\text { dan membingungkan }\end{array}$ & $1-5$ \\
\hline $\begin{array}{l}\text { Modul yang diberikan mudah } \\
\text { dipahami dan tersusun secara } \\
\text { sistematis }\end{array}$ & $1-5$ \\
\hline
\end{tabular}

\begin{tabular}{|c|c|c|}
\hline 3 & $\begin{array}{l}\text { Media zoom yang digunakan untuk } \\
\text { workshop sangat baik dan kegiatan } \\
\text { berialan lancar }\end{array}$ & $1-5$ \\
\hline
\end{tabular}

Kuesioner dibagikan melalui bantuan platform google yang kemudian diisi oleh peserta sebanyak 36 orang. Setelah pengisian kuesioner dilakukan penghitungan skor berdasarkan isian data tersebut, yang selanjutnya dihitung nilai rerata per aspek, dilanjutkan dengan rerata secara keseluruhan. Untuk lebih jelasnya berikut dilampirkan tampilan kuesioner yang dibagikan melalui google form.

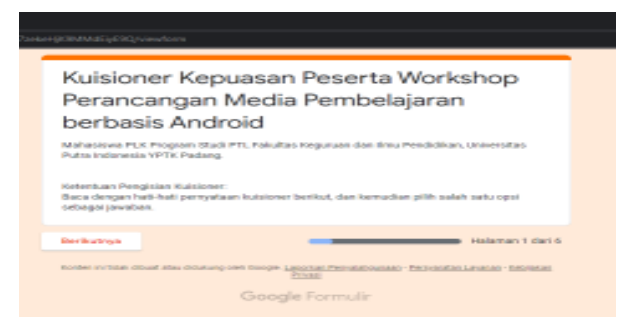

Gambar 8. Tampilan Awal Kuesioner

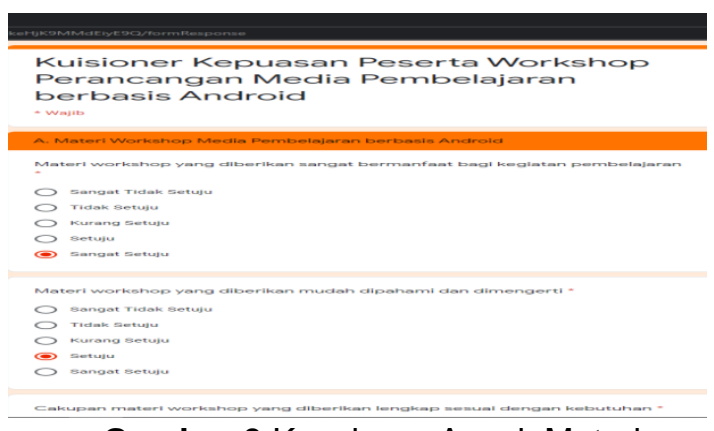

Gambar 9.Kuesioner Aspek Materi
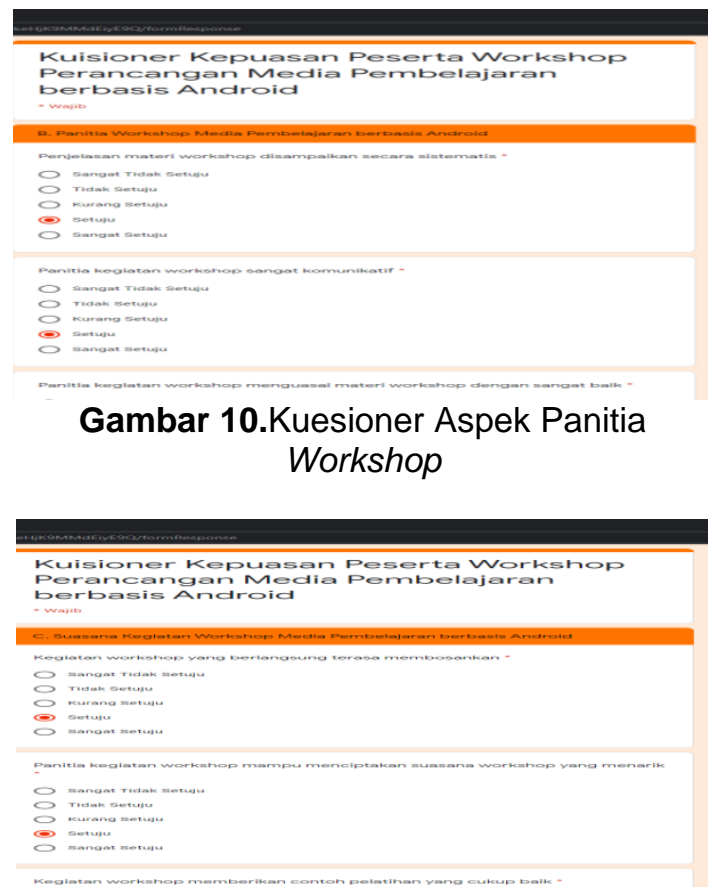

Gambar 11.Kuesioner Aspek Suasana PKM 


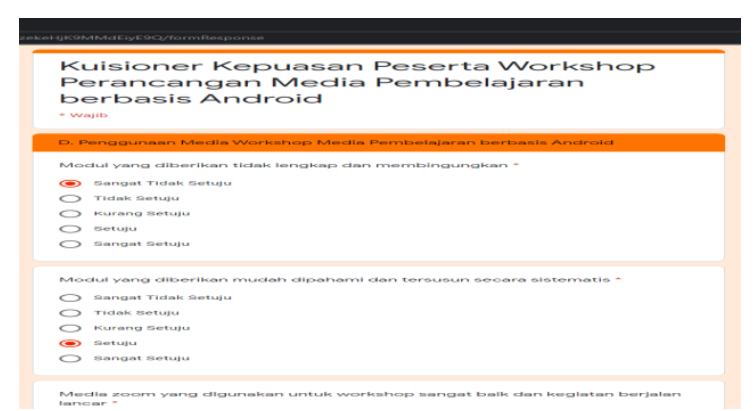

Gambar 12.Kuesioner Aspek Media

Rincian pengisian kuesioner oleh peserta workshop atau pelatihan kemudian dilakukan penghitungan skor dan rata-rata per aspek yang dinilai. Setelah skor rata-rata per aspek didapatkan kemudian dihitung skor ratarata secara keseluruhan. Lebih lengkap dapat dilihat pada rincian tabel berikut.

Tabel 3. Kuesioner Tingkat Kepuasan Workshop Perancangan Media Pembelajaran Berbasis Android

\begin{tabular}{|c|c|c|c|c|c|c|c|}
\hline \multicolumn{2}{|c|}{$\begin{array}{l}\text { A. Materi Workshop } \\
\text { Media Pembelajaran } \\
\text { berbasis Android }\end{array}$} & 1 & 2 & 3 & 4 & 5 & Rata \% \\
\hline 1 & $\begin{array}{l}\text { Materi workshop } \\
\text { yang diberikan } \\
\text { sangat } \\
\text { bermanfaat bagi } \\
\text { kegiatan } \\
\text { pembelajaran }\end{array}$ & 0 & 0 & 1 & 15 & 20 & 90,56 \\
\hline 2 & $\begin{array}{l}\text { Materi workshop } \\
\text { yang diberikan } \\
\text { mudah dipahami } \\
\text { dan dimengerti }\end{array}$ & 0 & 0 & 0 & 17 & 19 & 90,56 \\
\hline 3 & $\begin{array}{l}\text { Cakupan materi } \\
\text { workshop yang } \\
\text { diberikan } \\
\text { lengkap sesuai } \\
\text { dengan } \\
\text { kebutuhan }\end{array}$ & 0 & 0 & 3 & 10 & 23 & 91,11 \\
\hline 4 & $\begin{array}{l}\text { Materi workshop } \\
\text { yang diberikan } \\
\text { sesuai dengan } \\
\text { harapan dan } \\
\text { kebutuhan saya } \\
\text { dalam kegiatan } \\
\text { pembelajaran }\end{array}$ & 0 & 0 & 3 & 12 & 21 & 90 \\
\hline 5 & $\begin{array}{l}\text { Materi workshop } \\
\text { yang diberikan } \\
\text { dapat saya } \\
\text { pahami dan } \\
\text { terima dengan } \\
\text { baik } \\
\end{array}$ & 0 & 0 & 4 & 7 & 25 & 91,67 \\
\hline & Rata-rata & & & & & & 90,78 \\
\hline & $\begin{array}{l}\text { anitia } \\
\text { kshop Media } \\
\text { lbelajaran } \\
\text { oasis Android }\end{array}$ & 1 & 2 & 3 & 4 & 5 & Rata \% \\
\hline 1 & $\begin{array}{l}\text { Penjelasan } \\
\text { materi workshop } \\
\text { disampaikan } \\
\text { secara } \\
\text { sistematis } \\
\end{array}$ & 0 & 0 & 2 & 15 & 19 & 89,44 \\
\hline 2 & $\begin{array}{l}\text { Panitia kegiatan } \\
\text { workshop } \\
\text { sangat } \\
\text { komunikatif }\end{array}$ & 0 & 0 & 4 & 7 & 25 & 91,67 \\
\hline
\end{tabular}

\begin{tabular}{|c|c|c|c|c|c|c|c|}
\hline 3 & $\begin{array}{l}\text { Panitia kegiatan } \\
\text { workshop } \\
\text { menguasai } \\
\text { materi workshop } \\
\text { dengan sangat } \\
\text { baik }\end{array}$ & 0 & 0 & 0 & 13 & 23 & 92,78 \\
\hline 4 & $\begin{array}{l}\text { Panitia } \\
\text { workshop } \\
\text { melaksanakan } \\
\text { kegiatan sesuai } \\
\text { dengan jadwal } \\
\text { yang sudah } \\
\text { ditetapkan }\end{array}$ & 0 & 0 & 5 & 12 & 19 & 87,78 \\
\hline \multirow[t]{2}{*}{5} & $\begin{array}{l}\text { Panitia } \\
\text { workshop } \\
\text { menyediakan } \\
\text { waktu untuk } \\
\text { kegiatan diskusi } \\
\text { selama dan } \\
\text { setelah kegiatan } \\
\text { berlangsung }\end{array}$ & 0 & 0 & 2 & 15 & 19 & 89,44 \\
\hline & Rata-rata & & & & & & 90,22 \\
\hline
\end{tabular}

\begin{tabular}{|c|c|c|c|c|c|c|}
\hline $\begin{array}{l}\text { C. Suasana } \\
\text { Kegiatan Workshop } \\
\text { Media Pembelajaran } \\
\text { berbasis Android }\end{array}$ & 1 & 2 & 3 & 4 & 5 & Rata \% \\
\hline $\begin{array}{ll} & \text { Kegiatan } \\
& \text { workshop yang } \\
1 & \text { berlangsung } \\
\text { terasa } \\
\text { membosankan }\end{array}$ & 20 & 13 & 3 & 0 & 0 & 89,44 \\
\hline $\begin{array}{l}\text { Panitia kegiatan } \\
\text { workshop } \\
\text { mampu } \\
\text { menciptakan } \\
\text { suasana } \\
\text { workshop yang } \\
\text { menarik }\end{array}$ & 0 & 0 & 4 & 10 & 22 & 90 \\
\hline $\begin{array}{l}\text { Kegiatan } \\
\text { workshop } \\
\text { memberikan } \\
\text { contoh pelatihan } \\
\text { yang cukup baik }\end{array}$ & 0 & 0 & 5 & 4 & 27 & 92,22 \\
\hline $\begin{array}{l}\text { Suasana } \\
\text { kegiatan } \\
\text { workshop yang } \\
\text { berlangsung } \\
\text { tidak interaktif }\end{array}$ & 19 & 17 & 0 & 0 & 0 & 90,56 \\
\hline $\begin{array}{l}\text { Panitia lainnya } \\
\text { sangat } \\
\text { membantu } \\
\text { selama kegiatan } \\
\text { berlangsung }\end{array}$ & 0 & 0 & 2 & 12 & 22 & 91,11 \\
\hline Rata-rata & & & & & & 90,66 \\
\hline $\begin{array}{l}\text { D. Penggunaan } \\
\text { Media Workshop } \\
\text { Media Pembelajaran } \\
\text { berbasis Android }\end{array}$ & 1 & 2 & 3 & 4 & 5 & Rata \% \\
\hline $\begin{array}{l}\text { Modul yang } \\
\text { diberikan tidak } \\
\text { lengkap dan } \\
\text { membingungkan }\end{array}$ & 17 & 17 & 2 & 0 & 0 & 88,33 \\
\hline $\begin{array}{l}\text { Modul yang } \\
\text { diberikan mudah } \\
\text { dipahami dan } \\
\text { tersusun secara } \\
\text { sistematis }\end{array}$ & 0 & 0 & 5 & 10 & 21 & 88,89 \\
\hline $\begin{array}{l}\text { Media zoom } \\
\text { yang digunakan } \\
\text { untuk workshop } \\
\text { sangat baik dan }\end{array}$ & 0 & 0 & 8 & 12 & 16 & 84,44 \\
\hline
\end{tabular}




\begin{tabular}{cc}
\hline $\begin{array}{l}\text { kegiatan } \\
\text { berjalan lancar }\end{array}$ \\
\hline Rata-rata & 87,22 \\
\hline Rata-rata Penilaian & 90,00 \\
\hline
\end{tabular}

Berdasarkan pada hasil pengisian kuesioner yang sudah dikonversikan ke dalam bentuk penilaian skor didapatkan rata-rata persentase pada aspek materi PKM adalah $90,78 \%$, pada aspek panitia PKM adalah 90,22\%, pada aspek suasana kegiatan PKM adalah $90,66 \%$,dan pada aspek penggunaan media PKM adalah 87,22\%. Berdasarkan keseluruhan penilaian didapatkan persentase tingkat kepuasan peserta pelatihan perancangan media pembelajaran adalah 90,00\% sehingga dapat disimpulkan bahwa peserta merasa sangat puas dengan kegiatan PKM yang diberikan.

\section{Pembahasan}

Ditelaah dari hasil kegiatan serta evaluasi kegiatan yang dilakukan dapat dinyatakan bahwa kegiatan pengabdian yang berupa workshop atau pelatihan media ajar berbasis android sukses dilaksanakan dengan lancar dan baik. Hal ini dapat dilihat dari antusiasme peserta workshop serta hasil kuesioner tingkat kepuasan peserta yang berada di rata-rata persentase $90,00 \%$. Tingkat kepuasan peserta ini dirujuk dari artikel yang memiliki tema serupa yaitu dari (Fuada et al., 2020). Berdasarkan pernyataan dari (Fuada et al., 2020) dan (Ananda, R., \& Amin, M, 2019) tingkat antusiasme dan tingkat kepuasan peserta workshop dalam bidang Internet of Things menunjukan hasil yang sangat baik. Media ajar android merupakan salah satu contoh dari penerapan Internet of Things, maka dapat disimpulkan bahwa hasil kegiatan pengabdian ini dapat dikatakan sesuai dengan hasil workshop atau pelatihan yang pernah dilakukan sebelumnya dengan tema yang serupa.

Adapun kelebihan dari kegiatan pengabdian ini yang ditemukan di lapangan adalah adanya peningkatan kemampuan mahasiswa PLK dalam perancangan media ajar android serta kemampuan mahasiswa dalam memberikan inovasi terhadap media ajar yang akan diterapkan pada kegiatan PLK nantinya. Selain kelebihan dari kegiatan pengabdian tentunya juga terdapat beberapa kekurangan atau kendala yang dihadapi ketika workshop dilaksanakan. Beberapa kendala diantaranya adalah kurang maksimalnya respon balik dari peserta karena sinyal internet yang kurang stabil, adanya beberapa peserta yang terkendala dalam mengimplementasikan simulasi materi karena aplikasi yang disediakan tidak kompatibel dengan perangkat peserta, dan juga kendala dalam kurangnya waktu diskusi antara peserta dan pemateri. Akan tetapi walaupun kegiatan mengalami beberapa kendala, tujuan dari kegiatan ini tercapai dengan cukup baik dilihat dari kemampuan peserta dalam merancang media ajar android.

\section{SIMPULAN DAN SARAN}

Perkembangan media pembelajaran tidak terlepas dari perkembangan teknologi khususnya teknologi informasi dan komunikasi. Media pembelajaran berbasis android merupakan salah satu bentuk perkembangan dari media pembelajaran yang memanfaatkan teknologi. Melalui media pembelajaran android kegiatan pembelajaran dapat dilaksanakan meskipun tidak melalui tatap muka secara langsung. Maka dari itu diperlukan pelatihan bagi guru ataupun calon guru untuk dapat merancang media pembelajaran android. Melalui kegiatan PKM yang berupa pelatihan perancangan media pembelajaran berbasis android dapat dilihat ketertarikan peserta serta kepuasan peserta terhadap kegiatan tersebut, yang dapat dilihat dari isian kuesioner dari peserta. Pada aspek materi yang berisikan empat pernyataan didapatkan rata-rata skor aspek materi adalah 90,78\%, pada aspek panitia didapatkan rata-rata skor adalah $90,22 \%$, pada aspek suasana didapatkan ratarata skor adalah $90,66 \%$, dan pada aspek media PKM didapatkan rata-rata skor adalah $87,22 \%$.

Berdasarkan pada hasil tersebut dapat dilihat bahwa rata-rata skor penilaian secara keseluruhan adalah 90,00\%, dan dapat dikategorikan sangat puas sesuai dengan tabel persentase kepuasan yang dinyatakan oleh (Fuada et al., 2020). Dengan demikian dapat dinyatakan bahwa kegiatan pelatihan ini sangat penting dan bermanfaat, sehingga diharapkan kegiatan ini dilanjutkan bagi tingkat guru lainnya.

\section{UCAPAN TERIMAKASIH}

Kegiatan pengabdian kepada masyarakat ini dapat terlaksana dengan baik dan lancar karena adanya dana hibah PKM dari Yayasan Pendidikan Tinggi Komputer Padang dan Universitas Putra Indonesia YPTK Padang. Serta dukungan, bantuan, dan arahan dari LPPM Universitas Putra Indonesia YPTK Padang dan Fakultas Keguruan dan IImu Pendidikan, khususnya pada Program Studi Pendidikan Teknik Informatika.

\section{DAFTAR RUJUKAN}

Atsani, K. L. G. M. Z. (2020). Transformasi media pembelajaran pada masa Pandemi 
COVID-19. Al-Hikmah: Jurnal Studi Islam, 1(1), 11.

Fransisca, M., Yunus, Y., Sutiasih, A. D., \& Saputri, R. P. (2019). Practicality of elearning as learning media in digital simulation subjects at vocational school in Padang. Journal of Physics: Conference Series, 1339(1), 012077.

Makaborang, Y., Lalupanda, E. M., Bano, V. O., Taranau, O. T. K., Endah, R. R. H., \& Njdoeroemana, Y. (2021). SIMULASI PEMBUATAN DAN PENGGUNAAN MEDIA PEMBELAJARAN BIOLOGI DI SMA NEGERI 1 KAMBERA. SELAPARANG. Jurnal Pengabdian Masyarakat Berkemajuan,4(2), 5. https://doi.org/10.31764/jpmb.v4i2.4375

Pakpahan, A. F., Ardiana, D. P. Y., Mawati, A. T., Wagiu, E. B., Simarmata, J., Mansyur, M. Z., \& Iskandar, A. (2020). Pengembangan Media Pembelajaran. Yayasan Kita Menulis.

Pangga, D., Ahzan, S., Gummah, S., \& Prayogi, S. (2021). PELATIHAN PEMBUATAN VIDEO PEMBELAJARAN UNTUK GURU MA AL-ISTIQOMAH NW BEDUS. SELAPARANG. Jurnal Pengabdian Masyarakat Berkemajuan,3(2), 4. https://doi.org/10.31764/jpmb.v3i2.1512

Purba, R. A., Rofiki, I., Purba, S., Purba, P. B., Bachtiar, E., Iskandar, A., \& Purba, B. (2020). Pengantar Media Pembelajaran. Yayasan Kita Menulis.

Saputri, R. P., \& Fransisca, M. (2020a). ANALISIS KEBUTUHAN SISWA TERHADAP MEDIA PEMBELAJARAN BERBASIS ANDROID MATA PELAJARAN SIMULASI DIGITAL. Prosiding Seminar Nasional Terapan Riset Inovatif (SENTRINOV), 6(1), 8.

Saputri, R. P., \& Fransisca, M. (2020b). Pengembangan Media Pembelajaran Berbasis Android pada Mata Pelajaran Simulasi Digital. Indonesian Journal of Computer Science, 9(2), 11. https://doi.org/https://doi.org/10.33022/ijc s.v9i2.304

Yunus, Y., \& Fransisca, M. (2020). Analisis kebutuhan media pembelajaran berbasis android pada mata pelajaran kewirausahaan. Jurnal Inovasi Teknologi Pendidikan, 7(2),

9. https://doi.org/https://doi.org/10.21831/jitp .v7i1.32424

Fuada, S., Ichsan, I. N., Pratama, H. P., Putri, D. I. H., Suranegara, G. M., Setyowati, E., \&Fauzi, A. (2020). Workshop Internet-OfThings untuk Guru dan Siswa Sekolah Menengah di Purwakarta, Jawa Barat, Guna Menunjang Kompetensi Era Industri
4.0. J-ABDIPAMAS (Jurnal Pengabdian Kepada Masyarakat), 4(2), 39-52.

Ananda, R., \& Amin, M. (2019). WORKSHOP PELATIHAN PERANCANGAN INTERNET OF THINGS BERBASIS ARDUINO UNO JENIS R3/R3 SMD DI SMK SWASTA KARYA UTAMA KOTA TANJUNGBALAI. Jurdimas (Jurnal Pengabdian Kepada Masyarakat) Royal, 2(2), 121-126. 